\title{
Hubungan Pengetahuan Ibu Balita Tentang Gizi Dan Asupan Makan Balita Dengan Status Gizi Balita Di Desa Mee Tanjong Usi Kecamatan Mutiara Timur Kabupaten Pidie Tahun 2019
}

\section{Relationship of Knowledge of Mother Toddlers About Nutrition and Food Intake of Toddlers with Nutritional Status of Toddlers in Mee Tanjong Usi Village, Mutiara Timur District, Pidie Regency in 2019}

\author{
Fauziah$^{1}$, Yuriska Muharamis Muna ${ }^{2}$ \\ Email: fauziah.sst@gmail.com ${ }^{1}$ \\ Dosen Akbid Darul Husada ${ }^{1,2}$
}

\begin{abstract}
ABSTRAK
Status gizi merupakan indikator penting karena anak usia di bawah lima tahun merupakan kelompok yang rentan terhadap kesehatan dan gizi. Penentuan status gizi salah satunya dapat digunakan yaitu dengan rumus berat badan dibanding umur. Tujuan Penelitian Untuk mengetahui Hubungan Pengetahuan Ibu Balita Tentang Gizi Dan Asupan Makan Balita Dengan Status Gizi. Desain Penelitian ini bersifat Analitik dengan pendekatan Cross sectional dengan sampel seluruh balita di Desa Mee Tanjong Usi Kecamatan Mutiara Timur berjumlah 75 orang. Hasil penelitian menunjukan bahwa dari hasil uji bivariat $P$-value $=0.001$ ada hubungan antara pengetahuan ibu balita tentang gizi dengan status gizi balita, dan asupan makan balita $P$-value $=$ 0.001 berarti ada hubungan antara asupan makan balita dengan status gizi balita. Penelitian ini diharapkan bermanfaat meningkatkan pengetahuan tentang gizi, asupan makan dan status gizi balita.
\end{abstract}

Kata kunci $\quad$ : Pengetahuan, Asupan makan, Status gizi

\section{ABSTRACT}

Nutritional status is an important indicator because children under the age of five are a vulnerable group to health and nutrition. One of the ways to determine nutritional status is the formula for weight compared to age. The research objective was to determine the relationship between the knowledge of under-five mothers about nutrition and food intake for toddlers with nutritional status. This research design is analytic with cross sectional approach with a sample of all children under five in Mee Tanjong Usi Village, Mutiara Timur District, totaling 75 
Journal of Healthcare Technology and Medicine Vol. 6 No. 1 April 2020

Universitas Ubudiyah Indonesia

e-ISSN : 261109X

people. The results showed that from the results of the bivariate test, $P$-value $=0.001$, there was

a relationship between the knowledge of under-five mothers about nutrition with the nutritional status of children under five, and the food intake for toddlers. This research is expected to be useful in increasing knowledge about nutrition, food intake and nutritional status of children under five.

Keywords: Knowledge, food intake, nutritional status

\section{PENDAHULUAN}

Gizi (Nutrition) merupakan suatu proses organisme menggunakan makanan yang dikonsumsi secara normal melalui proses digesti, absorpsi, transportasi, penyimpanan, metabolisme, dan pengeluaran zat-zat yang tidak digunakan, untuk mempertahankan kehidupan, pertumbuhan dan fungsi normal dari organ-organ, serta menghasilkan energi (Sulistyoningsih, 2011). UNICEF melaporkan sebanyak 167 juta anak usia pra-sekolah di dunia yang menderita gizi kurang (underweight) sebagian besar berada di Asia Selatan (Gupta, et al., 2016). Status gizi merupakan keadaan yang dapat menggambarkan gizi seseorang apakah tergolong gizi baik, gizi kurang, gizi buruk, atau gizi lebih. Data Profil Kesehatan Provinsi Aceh (2012), menunjukkan prevalensi gizi di kabupaten Pidie yaitu gizi baik sebesar 85,9\%, gizi kurang sebesar 13,4\%, gizi buruk sebesar 0,2\%, dan gizi lebih sebesar 0,6\% (Dinkes Aceh, 2012).

Faktor-faktor yang mempengaruhi gizi balita adalah pengetahuan, persepsi, kebiasaan atau pantangan, kesukaan jenis makanan tertentu, jarak kelahiran yang terlalu dekat, sosial ekonomi dan penyakit infeksi (Proverawati,A.W.,2010).

Berdasarkan data yang diperoleh dari Dinas Kesehatan Kabupaten Pidie, menunjukkkan bahwa jumlah balita di Kabupaten Pidie tahun 2013 adalah 17.552 dan jumlah balita di Kecamatan Pidie tahun 2013 adalah 1.277 orang. Status gizi balita di Kecamatan Pidie yaitu normal 896 orang, pendek 203 orang dan sangat pendek 63 orang. Sedangkan status gizi menurut BB/TB 
Journal of Healthcare Technology and Medicine Vol. 6 No. 1 April 2020

Universitas Ubudiyah Indonesia

e-ISSN : 261109X

menunjukkan gizi buruk sebanyak 63 orang, gizi normal 1.053 orang, gizi kurus 102 orang dan gizi gemuk 3 orang. Dan berdasarkan pengukuran BB/U menunjukkan gizi baik 975 orang, gizi kurang 12 orang, gizi buruk 22 orang dan gizi lebih 4 orang.

Berdasarkan studi pendahuluan di Desa Mee Tanjong Usi terdapat 75 balita, jumlah balita BGM (Bawah Garis Merah) sebanyak 1 orang, jumlah balita BGK (Bawah Garis Kuning) sebanyak 2 orang. Berdasarkan survey awal yang dilakukan di Desa Desa Mee Tanjong Usi Kecamatan Mutiara Timur Tahun 2018 kepada 10 orang ibu yang memiliki balita, 6 orang diantaranya memiliki balita dengan asupan gizi kurang dan tidak mengetahui tentang gizi dan status gizi balita.

Berdasarkan latar belakang di atas, maka dalam penelitian ini ditentukan judul: "Hubungan Pengetahuan Ibu Balita Dan Pendapatan Keluarga Dengan Status Gizi Balita Di Desa Mee Tanjong Usi Kecamatan Mutiara Timur Kabupaten Pidie Tahun 2018”.

\section{METODE PENELITIAN}

Penelitian ini merupakan penelitian analitik, dengan menggunakan pendekatan cross sectional. Penelitian dilakukan di Desa Mee Tanjong Usi Kecamatan Mutiara Timur Kabupaten Pidie pada tanggal 28 Oktober 2019 dengan sampel seluruh balita Di Mee Tanjong Usi berjumlah 75 orang. Analisa Data dilakukan dengan analisis univariat dan Bivariat.

\section{HASIL}

\section{HUBUNGAN PENGETAHUAN IBU BALITA DENGAN STATUS GIZI}


TABEL 1

HUBUNGAN PENGETAHUAN IBU BALITA DENGAN STATUS GIZI BALITA DI DESA MEE TANJONG USI KECAMATAN MUTIARA TIMUR KABUPATEN PIDIE

Sumber data : Data Primer (diolah tahun 2019)

\begin{tabular}{|c|c|c|c|c|c|c|c|c|c|c|c|c|}
\hline \multirow{3}{*}{ No } & \multirow{3}{*}{ Pengetahuan } & \multicolumn{8}{|c|}{ Status Gizi } & \multirow{3}{*}{$\mathbf{F}$} & \multirow{3}{*}{$\%$} & \multirow{3}{*}{$\begin{array}{l}P \\
\text { Value }\end{array}$} \\
\hline & & \multicolumn{2}{|c|}{ Gizi Buruk } & \multicolumn{2}{|c|}{ Gizi Kurang } & \multicolumn{2}{|c|}{ Gizi Baik } & \multicolumn{2}{|c|}{ Gizi Lebih } & & & \\
\hline & & $\mathbf{F}$ & $\%$ & $\mathbf{F}$ & $\%$ & $\mathbf{F}$ & $\%$ & $\mathbf{F}$ & $\%$ & & & \\
\hline 1 & Baik & 0 & 0 & 3 & 12,0 & 22 & 88,0 & 0 & 0 & 25 & 100 & \\
\hline 2 & Cukup & 0 & 0 & 16 & 47,1 & 13 & 38,2 & 5 & 14,7 & 34 & 100 & \\
\hline 3 & Kurang & 0 & 0 & 8 & 50,0 & 8 & 50,0 & 0 & 0 & 16 & 100 & 0,001 \\
\hline \multicolumn{2}{|c|}{ Jumlah } & \multicolumn{2}{|l|}{0} & \multicolumn{2}{|l|}{27} & \multicolumn{2}{|l|}{43} & \multicolumn{2}{|l|}{5} & 75 & 100 & \\
\hline
\end{tabular}

Hasil analisa statistic menggunakan uji Chi-Square dengan nilai $\mathrm{P}$ value $=0,001<0,05$ hal tersebut berarti Ho ditolak dan Ha diterima, maka Ada Hubungan Antara Pengetahuan Ibu Balita Dengan Status Gizi Balita Di Desa Mee Tanjong Usi Kecamatan Mutiara Timur Kabupaten Pidie Tahun 2019. 
Journal of Healthcare Technology and Medicine Vol. 6 No. 1 April 2020

Universitas Ubudiyah Indonesia

e-ISSN : $261109 \mathrm{X}$

2. HUBUNGAN ASUPAN MAKAN BALITA DENGAN STATUS GIZI

TABEL 2

HUBUNGAN ASUPAN MAKAN BALITA DENGAN STATUS GIZI

BALITA DI DESA MEE TANJONG USI KECAMATAN MUTIARA TIMUR

\begin{tabular}{|c|c|c|c|c|c|c|c|c|c|c|c|c|}
\hline \multirow{3}{*}{ No } & \multirow{3}{*}{ Asupan Makan } & \multicolumn{8}{|c|}{ Status Gizi } & \multirow{3}{*}{$\mathbf{F}$} & \multirow{3}{*}{$\%$} & \multirow{3}{*}{$\begin{array}{l}P \\
\text { Value }\end{array}$} \\
\hline & & \multicolumn{2}{|c|}{ Gizi Buruk } & \multicolumn{2}{|c|}{ Gizi Kurang } & \multicolumn{2}{|c|}{ Gizi Baik } & \multicolumn{2}{|c|}{ Gizi Lebih } & & & \\
\hline & & $\mathbf{F}$ & $\%$ & $\mathbf{F}$ & $\%$ & $\mathbf{F}$ & $\%$ & $\mathbf{F}$ & $\%$ & & & \\
\hline 1 & Baik & 0 & 0 & 14 & 25,5 & 36 & 65,5 & 5 & 9,0 & 55 & 100 & \\
\hline 2 & Kurang & 0 & 0 & 13 & 65,0 & 7 & 35,0 & 0 & 0 & 20 & 100 & \\
\hline \multicolumn{2}{|c|}{ Jumlah } & \multicolumn{2}{|l|}{0} & \multicolumn{2}{|l|}{27} & \multicolumn{2}{|l|}{43} & \multicolumn{2}{|l|}{5} & 75 & 100 & 0,001 \\
\hline
\end{tabular}

\section{KABUPATEN PIDIE}

Sumber data : Data Primer (diolah tahun 2019)

Hasil analisa statistic menggunakan uji Chi-Square dengan nilai $\mathrm{P}$ value $=0,005<0,05$ hal tersebut berarti Ho ditolak dan Ha diterima, maka Ada Hubungan Antara Asupan Makan Balita Dengan Status Gizi Balita Di Desa Mee Tanjong Usi Kecamatan Mutiara Timur Kabupaten Pidie Tahun 2019.

\section{PEMBAHASAN}

a. Hubungan Pengetahuan Ibu Balita Dengan Status Gizi Balita

Berdasarkan tabel 5.6 diatas menunjukkan bahwa dari 25 responden yang pengetahuan baik dengan status gizi balita kurang sebanyak 3 responden $(12,0 \%)$ dan status gizi balita baik sebanyak 22 responden $(88,0 \%)$, dari 34 responden yang pengetahuan cukup dengan status gizi balita kurang sebanyak 16 responden (47,1\%), status gizi balita baik sebanyak 13 responden $(38,2 \%)$, dan status gizi balita lebih sebanyak 5 responden (14,7\%) sedangkan 
Journal of Healthcare Technology and Medicine Vol. 6 No. 1 April 2020

Universitas Ubudiyah Indonesia

e-ISSN : 261109X

dari 16 responden dengan pengetahuan kurang dengan status gizi balita kurang 8 responden $(50,0 \%)$, status gizi baik 8 responden $(50,0 \%)$.

Hasil analisa statistic menggunakan uji Chi-Square dengan nilai $\mathrm{P}$ value $=0,001<0,05$ hal tersebut berarti Ho ditolak dan Ha diterima, maka Ada Hubungan Antara Pengetahuan Ibu Balita Dengan Status Gizi Balita Di Desa Mee Tanjong Usi Kecamatan Mutiara Timur Kabupaten Pidie Tahun 2018.

Berdasarkan hasil penelitian, penulis berasumsi bahwa pengetahuan mempengaruhi status gizi balita, sesuai dengan hasil penelitian, ibu yang berpengetahuan baik, memiliki balita dengan status gizi baik. Semakin baik pengetahuan ibu maka semakin baik juga status gizi balita.

Pengetahuan bukan faktor langsung yang mempengaruhi status gizi anak balita, namun pengetahuan gizi memiliki peran penting, karena dengan memiliki pengetahuan yang cukup khususnya dibidang kesehatan, seseorang dapat mengetahui berbagai macam gangguan kesehatan yang mungkin akan timbul sehingga dapat dicari pemecahannya (Notoatmodjo, 2010).

b. Hubungan Asupan Makan Balita Dengan Status Gizi Balita

Berdasarkan tabel 5.7 diatas menunjukkan bahwa dari 55 responden yang memiliki asupan makan baik dengan status gizi balita kurang sebanyak 14 responden $(25,5 \%)$, status gizi balita baik sebanyak 36 responden $(65,5 \%)$, dan status gizi balita lebih sebanyak 5 responden $(9,0 \%)$, sedangkan dari 20 responden yang memiliki asupan makan kurang dengan status gizi balita kurang sebanyak 13 responden $(65,0 \%)$, dan status gizi balita baik sebanyak 7 responden $(35,0 \%)$. 
Journal of Healthcare Technology and Medicine Vol. 6 No. 1 April 2020

Universitas Ubudiyah Indonesia

e-ISSN : $261109 x$

Hasil analisa statistic menggunakan uji Chi-Square dengan nilai $\mathrm{P}$ value $=0,005<0,05$ hal tersebut berarti Ho ditolak dan Ha diterima, maka Ada Hubungan Antara Asupan Makan Balita Dengan Status Gizi Balita Di Desa Mee Tanjong Usi Kecamatan Mutiara Timur Kabupaten Pidie Tahun 2018.

Asupan makan adalah berbagai informasi yang memberikan gambaran mengenai jumlah dan jenis bahan makanan yang dimakan setiap hari oleh satu orang dan merupakan ciri khas untuk suatu kelompok masyarakat tertentu. Asupan makan dapat diartikan suatu kebiasaan menetap dalam hubungan dengan konsumsi makan yaitu berdasarkan jenis bahan makanan : makanan pokok, sumber protein, sayur, buah, dan berdasarkan frekuensi: harian, mingguan, pernah, dan tidak pernah sama sekali. Dalam hal pemilihan makanan dan waktu makan manusia dipengaruhi oleh usia, selera pribadi, kebiasaan, budaya dan sosial ekonomi (Almatsier, 2008).

Asupan makan yang baik mengandung makanan sumber energi, sumber zat pembangun dan sumber zat pengatur, karena semua zat gizi diperlukan untuk pertumbuhan dan pemiliharaan tubuh serta perkembangan otak dan produktifitas kerja, serta dimakan dalam jumlah cukup sesuai dengan kebutuhan. Dengan pola makan sehari-hari yang seimbang dan aman, berguna untuk mencapai dan mempertahankan status gizi dan kesehatan yang optimal (Almatsier, S. dkk. 2011).

\section{KESIMPULAN}

Setelah dilakukan uji statistik tentang Hubungan Pengetahuan Ibu Balita Dan Asupan Makan Balita Dengan Status Gizi Balita Di Desa Mee Tanjong Usi Kecamatan Mutiara Timur 
Journal of Healthcare Technology and Medicine Vol. 6 No. 1 April 2020

Universitas Ubudiyah Indonesia

e-ISSN : 261109X

Kabupaten Pidie, dapat disimpulkan ada hubungan antara pengetahuan ibu balita dengan status gizi balita, dengan hasil uji statistik didapatkan nilai $P$ Value 0,001. Ada hubungan antara asupan makan balita dengan status gizi balita, dengan hasil uji statistik didapatkan nilai $P$ Value 0,005 .

\section{SARAN}

Penelitian ini di harapkan dapat di jadikan Sebagai bahan informasi dan penambah pengetahuan masyarakat tentang status gizi balita sehingga dapat meningkatkan kesadaran keluarga tentang pentingnya memperhatikan status gizi pada balita.

\section{DAFTAR PUSTAKA}

Adriani, M dan Wirjatmadi, B. (2012). Gizi dan Kesehatan Balita Peranan Mikro ZinC pada Pertumbuhan Balita. Kencana. Jakarta : 124-127

Amin Widjaja, (2008),Dasar Dasar Customer Relationship.Management.Harvarindo, Jakarta.

Dinas Kesehatan Provinsi Aceh, Profil (2015), Banda Aceh.

Fitriani, S.(2011). Promosi Kesehatan. Cetakan 1.Yogyakarta: Graha Ilmu.

Hidayat, A. Aziz Alimul, (2008),Pengantar Kebutuhan Dasar Manusia: Aplikasi Konsep dan Proses Keperawatan Buku 1, Jakarta: Salemba Medika

Hockenberry, M. J., Wilson, D. \& Rodgers, C. C.(2016). Wong's Essentials of Pediatric Nursing. s.l.:Elsevier.

Kemenkes RI. Profil Kesehatan Indonesia tahun (2016). Jakarta : Kemenkes RI; 2016.

Kemenkes RI, (2010). Riset Kesehatan Dasar (Riskesdas) 2010.

Marmi. (2013). Gizi Dalam Kesehatan Reproduksi. Yogyakarta : Pustaka Belajar

Muaris, H. 2006. Lauk Bergizi Untuk Anak Balita. Jakarta: Gramedia Pustaka Utama

Notoatmodjo,S.(2012).Metodologi Penelitian Kesehatan. Jakarta: Rineka Cipta. 
Journal of Healthcare Technology and Medicine Vol. 6 No. 1 April 2020

Universitas Ubudiyah Indonesia

e-ISSN : 261109X

Price, D. L. \& Gwin, J. F. (2008). Pediatric Nursing : An Introductory Text. Canada: Elsevier

Proverawati, A. (2011). Anemia dan Anemia Kehamilan. Yogyakarta : Nuha Medika.

Sukmawandari, B. (2015). Faktor-Faktor yang Berhubungan Dengan Status Gizi balita 1-5 Tahun di Desa Klepu Kecamatan Pringapus. Skripsi (diunduh 4 Juni 2016).

Sulistyoningsih, Hariyani. (2011). Gizi Untuk Kesehatan Ibu dan Anak. Yogyakarta: Graha Ilmu.

Sutomo B dan Anggraini DY. (2010). Menu Sehat Alami Untuk Balita \& Batita. Jakarta : PT. Agromedia Pustaka

Turnip, Frisda (2008). Pengaruh"Positive Deviance" Pada Ibu Dari Keluarga Miskin Terhadap Status Gizi Anak Usia 12-24 Bulan di Kecamatan Sidikalang Kabupaten Dairi tahun 2007’. USU Respository 2008.

Werner, Thuman \& Maxwell. (2010). Apa yang Anda Kerjakan Bila Tidak Ada Dokter. Yogyakarta. Penerbit: Andi Offset. 